
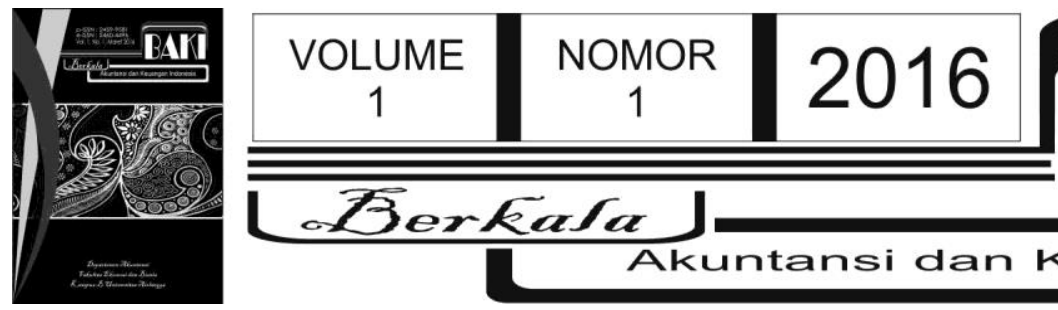

Berkata

Akuntansi dan Keuangan Indonesia

\title{
Good Governance Pengelolaan Keuangan Desa Menyongsong Berlakunya Undang-Undang No. 6 Tahun 2014
}

\author{
Titiek Puji Astuti*, Yulianto \\ *Universitas Setia Budi Surakarta \\ *titiekpujiastuti@gmail.com
}

\begin{tabular}{|c|c|}
\hline INFOARTIKEL & ABSTRAK \\
\hline $\begin{array}{l}\text { Histori Artikel: } \\
\text { Tanggal Masuk } 26 \text { Oktober } 2015 \\
\text { Tanggal Diterima } 22 \text { Februari } 2016 \\
\text { Tersedia Online } 31 \text { Maret } 2016 \\
\text { Keywords: } \\
\text { Good Governance; } \\
\text { Keuangan Desa }\end{array}$ & $\begin{array}{l}\text { Seluruh desa di Indonesia diperkirakan sudah akan menerima } \\
\text { kucuran dana transfer dari Anggaran Pendapatan dan Belanja } \\
\text { Negara (APBN). Setiap desa yang saat ini jumlahnya mencapai } 72 \\
\text { ribu di seluruh Indonesia, akan memperoleh anggaran berkisar Rp } \\
800 \text { juta hingga Rp } 1,4 \text { miliar per desa. Oleh karena itu, perlu adanya } \\
\text { tata kelola yang baik dalam pengelolaan keuangan desa. Good } \\
\text { Governance diajukan demi tercapainya pengelolaan manajemen yang } \\
\text { lebih transparan bagi semua penggunaan laporan keuangan. } \\
\text { Penelitian ini dilakukan dengan metode studi kasus (case study) } \\
\text { yakni, pengamatan secara detail terhadap obyek atau orang. Lokasi } \\
\text { penelitian yang dipilih sebagai studi kasus adalah desa-desa yang } \\
\text { ada di Kecamatan Polokarto, Sukoharjo Jawa Tengah. Teknik analisa } \\
\text { yang digunakan yakni logic analytic. Hasil penelitian ini adalah } \\
\text { adanya transparansi, akuntabel dan partisipasi dalam pengelolaan } \\
\text { keuangan desa karena itu merupakan aspek penting dalam } \\
\text { menciptakan good governance dalam pengelolaan keuangan desa } \\
\text { yang telah tertuang dalam UU No.14 tentang Desa. Hambatan dalam } \\
\text { pelaksanaan good governance pengelolaan keuangan desa yaitu } \\
\text { sumber daya manusia yang ada di pemerintahan desa yang tidak } \\
\text { cakap. }\end{array}$ \\
\hline
\end{tabular}

\section{Pendahuluan}

Seluruh desa di Indonesia diperkirakan sudah akan menerima kucuran dana transfer dari Anggaran Pendapatan dan Belanja Negara (APBN), Juli 2014 mendatang. Setiap desa yang saat ini jumlahnya mencapai 72 ribu di seluruh Indonesia, akan memperoleh anggaran berkisar Rp 800 juta hingga Rp 1,4 miliar per desa. Pengucuran anggaran akan berbeda-beda untuk setiap desa, karena disesuaikan dengan luas desa, jumlah penduduk dan tingkat kebutuhan hidup di desa tersebut. Setiap desa akan mendapatkan alokasi dana yang berasal dari dua sumber. Dana transfer (dari APBN) jumlahnya Rp 59,2 triliun. Kemudian alokasi dana desa dari kabupaten. Jadi bisa-bisa setiap desa mendapatkan lebih dari Rp 1 miliar setiap tahun. Transfer dana tersebut hanya untuk desa. Sementara terkait kelurahan tidak termasuk dalam program penerima anggaran. Alasannya, karena 
kelurahan masuk struktur pemerintahan. Sementara desa merupakan sebuah komunitas besar dan satu kesatuan dengan masyarakat hukum adat. Inti dari pengucuran dana transfer ini titik beratnya pada pembangunan desa. Jadi bukan pemerintahan desa. Jangan sampai karena salah dalam pengelolaan pemerintah desa berurusan dengan aparat penegak hukum. Pemerintah pusat tentu akan memberi pendidikan kepada para kepala desa dalam pengelolaan keuangan desa.

Menurut UU No. 6 Tahun 2014 menyatakan bahwa:

"Desa adalah desa dan desa adat atau yang disebut dengan nama lain, selanjutnya disebut Desa, adalah kesatuan masyarakat hukum yang memiliki batas wilayah yang berwenang untuk mengatur dan mengurus urusan pemerintahan, kepentingan masyarakat setempat berdasarkan prakarsa masyarakat, hak asal usul, dan/atau hak tradisional yang diakui dan dihormati dalam sistem pemerintahan Negara Kesatuan Republik Indonesia."

Pengaturan Desa bertujuan:

a. memberikan pengakuan dan penghormatan atas desa yang sudah ada dengan keberagamannya sebelum dan sesudah terbentuknya Negara Kesatuan Republik Indonesia;

b. memberikan kejelasan status dan kepastian hukum atas desa dalam sistem ketatanegaraan Republik Indonesia demi mewujudkan keadilan bagi seluruh rakyat Indonesia;

c. melestarikan dan memajukan adat, tradisi, dan budaya masyarakat desa;

d. mendorong prakarsa, gerakan, dan partisipasi masyarakat desa untuk pengembangan potensi dan aset desa guna kesejahteraan bersama;

e. membentuk pemerintahan desa yang profesional, efisien dan efektif, terbuka, serta bertanggung jawab;

f. meningkatkan pelayanan publik bagi warga masyarakat desa guna mempercepat perwujudan kesejahteraan umum;

g. meningkatkan ketahanan sosial budaya masyarakat desa guna mewujudkan masyarakat desa yang mampu memelihara kesatuan sosial sebagai bagian dari ketahanan nasional;

h. memajukan perekonomian masyarakat desa serta mengatasi kesenjangan pembangunan nasional; dan

i. memperkuat masyarakat desa sebagai subjek pembangunan.

Undang-Undang No. 6 Tahun 2014 juga mengatur penataan desa. Penataan desa bertujuan mewujudkan efektivitas penyelenggaraan pemerintahan desa; mempercepat peningkatan kesejahteraan masyarakat desa; mempercepat peningkatan kualitas pelayanan publik; meningkatkan kualitas tata kelola pemerintahan desa; dan meningkatkan daya saing desa. Corporate Governance merupakan konsep yang diajukan demi peningkatan kinerja perusahaan melalui supervise atau monitoring kinerja manajemen dan menjamin akuntabilitas manajemen terhadap stakeholder dengan mendasarkan pada kerangka peraturan.

Konsep Corporate Governance diajukan demi tercapainya pengelolaan perusahaan yang lebih transparan bagi semua penggunaan laporan keuangan. Bila konsep ini diterapkan dengan baik maka transparansi pengelolaan perusahaan akan terus membaik dan diharapkan pertumbuhan ekonomi akan terus meningkat dan akan menguntungkan bagi banyak pihak (Prasojo dan Kurniawan, 2008). 
Begitu juga dengan desa. Sesuai dengan tujuan penataan desa maka diperlukan tata kelola yang baik (corporate governance). Corporate governance yang baik maka akan mempercepat peningkatan kesejahteraan masyarakat desa.

Corporate Governance diajukan demi tercapainya pengelolaan manajemen yang lebih transparan bagi semua penggunaan laporan keuangan. Salah satu tujuan penataan desa adalah meningkatkan kualitas tata kelola pemerintahan desa. Berdasarkan latar belakang di atas masalah penelitian ini adalah bagaimana corporate governance dalam pengelolaan keuangan desa menyongsong berlakunya Undang-Undang No. 6 Tahun 2014 dan hambatan-hambatan apa saja yang ditemui dalam pelaksanaan pengelolaan keuangan desa. Tujuan dalam penelitian ini adalah untuk mengetahui bagaimana corporate governance dalam pengelolaan keuangan desa menyongsong berlakunya Undang-Undang No. 6 Tahun 2014 dan untuk mengetahui hambatanhambatan apa saja yang ditemui dalam pelaksanaan pengelolaan keuangan desa. Kontribusi penelitian ini adalah untuk memperdalam khasanah ilmu corporate governance dalam pengelolaan keuangan di sektor publik serta bagi pemerintah untuk mengevaluasi kebijakan tentang pengelolaan keuangan desa.

\section{Tinjauan Pustaka}

\subsection{Landasan Teori}

Sebagaimana yang telah dikemukakan oleh Wolfensohn, Presiden of the World Bank (1999), terdapat dua teori utama yang terkait dengan Corporate Governance adalah stewardship theory dan agency theory (Hardikasari 2011). Stewardship theory dibangun di atas asumsi filosofis mengenai sifat manusia yakni bahwa manusia pada hakekatnya dapat dipercaya, mampu bertindak dengan penuh tanggung jawab memiliki integrasi, dan kejujuran terhadap pihak lain. Dengan kata lain, stewardship theory memandang manajemen sebagai dapat dipercaya untuk bertindak dengan sebaik-baiknya bagi kepentingan publik pada umumnya maupun shareholders pada khususnya.

Menurut Zimmerman (1977) agency problem juga ada dalam konteks organisasi pemerintahan. Rakyat sebagai principles memberikan mandat kepada pemerintah sebagai agen, untuk menjalankan tugas pemerintahan dalam rangka meningkatkan kesejahteraan rakyat. Dalam konteks lain, politisi dapat juga disebut principles karena menggantikan peran rakyat, namun dapat juga dipandang sebagai agen karena menjalankan tugas pengawasan yang diberikan oleh rakyat. Implikasi dari teori ini, principles baik rakyat secara langsung perlu melakukan pengawasan kepada agen baik pemerintah maupun para politisi. Politisi sebagai prinsipel juga memerlukan informasi untuk mengevaluasi jalannya pemerintah.

Moe (1984) mengemukakan bahwa hubungan prinsipal dan agen dapat dilihat dalam politik demokrasi. Masyarakat adalah prinsipal, politisi (legislatif) adalah agen mereka. Politisi (legislatif) adalah prinsipal, birokrat/pemerintah adalah agen mereka. Pejabat pemerintahan adalah prinsipal, pegawai pemerintahan adalah agen mereka. Keseluruhan politik tersusun dari alur hubungan 
prinsipal-agen, dari masyarakat hingga level terendah pemerintahan. Nyoto dan Fadzil (2011) juga menyatakan bahwa terdapat hubungan prinsipal-agen antara pemerintah pusat dan pemerintah daerah. Pemerintah pusat adalah prinsipal dan pemerintah daerah bertindak sebagai agen. Hal ini dikarenakan, Indonesia sebagai negara kesatuan, pemerintah daerah bertanggung jawab kepada msayarakat sebagai pemilih dan juga kepada pemerintah pusat.

Dalam konteks teori signalling, pemerintah berusaha untuk memberikan sinyal yang baik kepada rakyat (Evans dan Patton 1987). Tujuannya agar rakyat dapat terus mendukung pemerintah yang saat ini berjalan sehingga pemerintahan dapat berjalan dengan baik. Laporan keuangan dapat dijadikan sarana untuk memberikan sinyal kepada rakyat. Kinerja pemerintahan yang baik perlu diinformasikan kepada rakyat baik sebagai bentuk pertanggungjawaban maupun sebagai bentuk promosi untuk tujuan politik.

APBD menurut UU Keuangan Negara ditetapkan sebagai peraturan daerah (perda). Peraturan daerah ini merupakan bentuk kontrak yang menjadi alat bagi legislatif untuk mengawasi pelaksanaan anggaran oleh eksekutif (Halim dan Abdullah 2006). Menurut Fadzil dan Nyoto (2011), hubungan keagenan menimbulkan asimetri informasi yang menimbulkan beberapa perilaku seperti oportunistik, moral hazard, dan adverse selection. Perilaku oportunistik dalam proses penganggaran contohnya, (1) anggaran memasukkan program yang berorientasi publik tetapi sebenarnya mengandung kepentingan pemerintah untuk membiayai kebutuhan jangka pendek mereka dan (2) alokasi program ke dalam anggaran yang membuat pemerintah lebih kuat dalam posisi politik terutama menjelang proses pemilihan, yaitu program yang menarik bagi pemilih dan publik dapat berpartisipasi di dalamnya.

\subsubsection{Corporate Governance}

Governance merupakan paradigma baru dalam tatanan pengelolaan kepemerintahan. Ada tiga pilar governance, yaitu pemerintah, sektor swasta, dan masyarakat. Sementara itu paradigma pengelolaan pemerintahan yang sebelumnya berkembang adalah government sebagai satu-satunya penyelenggara pemerintahan. Dengan bergesernya paradigma dari government kearah governance, yang menekankan pada kolaborasi dalam kesetaraan dan keseimbangan antara pemerintah, sektor swasta, dan masyarakat madani (civil society), maka dikembangkan pandangan atau paradigma baru administrasi publik yang disebut dengan kepemerintahan yang baik (good governance) (Mardiasmo 2002).

Dalam rangka mendukung terwujudnya tata kelola yang baik (good governance) dalam penyelenggaraan desa, pengelolaan keuangan desa dilakukan berdasarkan prinsip tata kelola yaitu transparan, akuntabel dan partisipatif serta dilakukan dengan tertib dan disiplin anggaran (Santosa 2008). 


\subsubsection{Transparansi (Transparancy)}

Dalam Pasal 4 ayat 7 Peraturan Menteri Dalam Negeri Republik Indonesia No. 13 Tahun 2006, tentang Pedoman Pengelolaan Keuangan Daerah, dikatakan transparan adalah prinsip keterbukaan yang memungkinkan masyarakat untuk mengetahui dan mendapatkan akses informasi seluasluasnya tentang keuangan daerah. Dengan adanya transparansi menjamin akses atau kebebasan bagi setiap orang untuk memperoleh informasi tentang penyelenggaraan pemerintahan, yakni informasi tentang kebijakan, proses pembuatan dan pelaksanannya, serta hasil-hasil yang dicapai. Transparansi yakni adanya kebijakan terbuka bagi pengawasan. Sedangkan yang dimaksud dengan informasi adalah informasi mengenai setiap aspek kebijakan pemerintah yang dapat dijangkau oleh publik. Keterbukaan informasi diharapkan akan menghasilkan persaingan politik yang sehat, toleran dan kebijakan dibuat berdasarkan pada preferensi publik (Bappenas 2003).

Prinsip-prinsip transparansi dapat diukur melalui sejumlah indikator seperti berikut: 1) Mekanisme yang menjamin sistem keterbukaan dan standarisasi dari semua proses pelayanan publik; 2) Mekanisme yang memfasilitasi pertanyaan-pertanyaan publik tentang berbagai kebijakan dan pelayanan publik, maupun proses-proses didalam sektor publik; 3) Mekanisme yang memfasilitasi pelaporan maupun penyebaran informasi maupun penyimpangan tindakan aparat publik didalam kegiatan melayani (Bappenas 2003).

\subsubsection{Akuntabilitas (Accountability)}

Akuntabilitas (accountability) adalah kewajiban untuk memberikan pertanggungjawaban atau menjawab dan menerangkan kinerja dan tindakan seseorang badan hukum pimpinan suatu organisasi kepada pihak yang memiliki hak atau berkewenangan untuk meminta keterangan atau pertanggungjawaban. Dalam pelaksanaan akuntabilitas dilingkungan instansi pemerintah, perlu diperhatikan prinsip-prinsip sebagai berikut:

a) harus ada komitmen dari pimpinan dan seluruh staf instansi untuk melakukan pengelolaan pelaksanaan misi agar akuntabel;

b) harus merupakan suatu sistem yang dapat menjamin penggunaan sumber-sumber daya secara konsisten dengan peraturan perundang-undangan yang berlaku;

c) harus dapat menunjukkan tingkat pencapaian tujuan dan sasaran yang telah ditetapkan;

d) harus berorientasi pada pencapaian visi dan misi serta hasil dan manfaat yang diperoleh;

e) harus jujur, objektif, transparan dan inovatif sebagai katalisator perubahan manajemen instansi pemerintah dalam bentuk pemutakhiran metode dan teknik pengukuran kinerja dan penyusunan laporan akuntabilitas (LAN dan BPKP 2000).

\subsubsection{Partisipasi}

Partisipasi menurut LAN dan BPKP (2000) adalah setiap warganegara mempunyai suara dalam pembuatan keputusan, baik secara langsung maupun melalui intermediasi institusi legitimasi yang 
mewakili kepentingannya. Partisipasi ini dibangun atas dasar kebebasan berasosiasi dan berbicara serta berpartisipasi secara konstruktif. Dalam Permendagri No. 37 Tahun 2007 tentang Pengelolaan Keuangan Desa, partisipasi memakai kata-kata partisipatif, yaitu keikutsertaan dan keterlibatan masyarakat secara aktif dalam proses pembangunan.

Partisipasi masyarakat dalam penentuan kebijakan publik menjadi kekuatan pendorong untuk mempercepat terpenuhinya prinsip akuntabilitas dari penyelenggara pemerintahan di desa. Dalam penganggaran partisipasi masyarakat sangat penting untuk mencegah kebijakan-kebijakan yang menyimpang. Prinsip dan indikator partisipasi masyarakat dalam pengganggaran menurut Sulistioni dan Hendriadi (2004) dalam Taufik (2013) mencakup hal-hal berikut:

a) adanya akses bagi partisipasi aktif publik dalam proses perumusan program dan pengambilan keputusan anggaran;

b) adanya peraturan yang memberikan tempat ruang kontrol oleh lembaga independen dan masyarakat baik secara perorangan maupun kelembagaan sebagai media check and balances;

c) adanya sikap proaktif pemerintah daerah untuk mendorong partisipasi warga pada proses penganggaran. Hal ini mengingat kesenjangan yang tajam antara kesadaran masyarakat tentang cara berpartisipasi yang efektif dan cita-cita mewujudkan APBD yang aspiratif.

\section{Metode Penelitian}

\subsection{Desain Penelitian}

Penelitian ini dilakukan dengan metode studi kasus (case study) yakni, pengamatan secara detail terhadap obyek atau orang, baik pada satu titik waktu atau beberapa titik waktu. Penelitian ini melibatkan data kualitatif, serta menggunakan logic analytic menurut Smith (2003) dalam Simanjuntak dan Januarsi (2011). Penelitian dilakukan melalui pengamatan langsung dilapangan yakni desa yang telah dipilih oleh peneliti atau dengan cara purposive sampling yakni sampel yang telah ditetapkan oleh peneliti dengan alasan dan tujuan khusus. Pengamatan dilakukan melalui keterlibatan secara langsung terhadap semua kegiatan yang dilakukan oleh obyek penelitian dalam waktu tertentu sehingga diperoleh gambaran utuh tentang pengelolaan keuangan desa, selain itu juga dilakukan wawancara secara tidak terstruktur selama proses pengamatan langsung tersebut.

Sebagai salah satu metode penelitian, studi kasus digunakan dalam banyak situasi untuk memberikan kontribusi terhadap ilmu pengetahuan, bagi individu, kelompok, organisasi, sosial dan politik, serta fenomena yang berhubungan satu dengan lainnya. Studi kasus banyak diterapkan pada penelitian-penelitian psikologi, ilmu politik, pekerja sosial, bisnis dan perencanaan sosial. Namun, pendekatan studi kasus tidak familiar pada penelitian-penelitian ilmu akuntansi atau ilmu ekonomi lainnya, keunggulan pendekatan studi kasus adalah peneliti mampu memenuhi semangat keingintahuan dalam memahami fenomena sosial yang terjadi dalam masyarakat, pendekatan ini akan memberikan pemahaman yang holistik terhadap peneliti akan arti dari karakteristik berbagai 
kejadian dalam kehidupan, seperti siklus kehidupan, organisasi, proses managerial, perubahan lingkungan, hubungan internasional dan transformasi industri (Yin 2003).

\subsection{Lokasi Studi Kasus}

Lokasi penelitian yang dipilih sebagai studi kasus adalah Desa Godog dan Desa Tepisari, Kecamatan Polokarto, Sukoharjo Jawa Tengah. Pemilihan lokasi studi kasus ini dilatarbelakangi karena pengelolaan keuangan dan administrasi yang cukup bagus tetapi ada kendala yang menghambat misalnya pemasukan desa yang tidak ada.

\subsection{Teknik Analisis}

Teknik analisa yang digunakan yakni logic analytic yakni menyesuaikan berbagai hasil pengamatan dan wawancara dengan teori yang digunakan dalam penelitian ini. Yakni, akuntansi dan good governance.

\section{Analisis dan Pembahasan}

\subsection{Analisis Data}

Penelitian ini dilakukan selama sepuluh bulan yaitu dari bulan Januari sampai bulan September. Pengucuran dana desa sampai bulan Oktober mencapai 80 persen dari anggaran yang dikucurkan Pemerintah Pusat. Berdasarkan hasil wawancara dan penelusuran dokumen dari Bagian Pemerintahan Desa Kabupaten Sukoharjo, Desa Godog, Desa Tepisari, Kecamatan Polokarto dan Kecamatan Kartasura dan data dari Kementerian Desa, Pembangunan Daerah Tertinggal, dan Transmigrasi diperoleh informasi berikut ini.

1. Konsep Pembangunan dalam Undang-Undang No. 6 Tahun 2014 tentang Desa. Berikut ini konsep pembangunan mengenai Desa, yaitu

a. Desa berusaha mandiri mengatasi sendiri berbagai permasalahan yang ada di desa baik di bidang fisik maupun non fisik dengan adanya dana desa yang cukup besar.

b. Desa harus berusaha meningkatkan partisipasi dan gotong royong masyarakat dalam pembangunan desa.

c. Desa dapat membuat perencanaan pembangunan sehingga dapat mempercepat pembangunan desa dalam rangka mewujudkan kesejahteraan masyarakat desa.

d. Tetap adanya pengawasan pembangunan yang ada di desa sehingga tidak melenceng dengan RPJMD Kabupaten.

e. Peningkatkan kualitas SDM aparat pemerintah desa sebagai garda terdepan dalam pembangunan, kemasyarakatan dan pelayanan terhadap masyarakat.

2. Landasan Hukum Implementasi UU Desa

a. Undang-undang No. 6 Tahun 2014 tentang Desa yang diikuti oleh: 
1). Permendagri tentang Pedoman Teknis Peraturan Desa; Pemilihan Kepala Desa; Keuangan Desa dan Pedoman Pembangunan Desa;

2). Permendes PDTT tentang kewenangan asal usul dan kewenangan lokal skala Desa; musyawarah desa; pendampingan desa; BUM Desa; prioritas pembangunan Desa.

b. Peraturan Pemerintah Tahun 2014 tentang Peraturan Pelaksanaan UU No. 6 Tahun 2014 tentang Desa.

c. Peraturan Pemerintah Tahun 2014 tentang Dana Desa yang bersumber dari APBN yang nantinya akan dikeluarkan R-PMK mengenai tatacara pengalokasian, penyaluran, penggunaan, pemantauan dan evaluasi dana desa.

d. Peraturan-peraturan yang mengkait perlu dibuat agar laporan keuangan desa bisa sesuai dengan sistem akuntansi pemerintahan daerah

3. Pengelolaan Keuangan Desa

a. Desa berpendapat agar besaran alokasi anggaran yang diperuntukkan langsung ke desa ditentukan dari wilayah dan tidak berdasarkan dari jumlah

b. Desa masih kekurangan perangkat yang mempunyai skil di bidang keuangan.

c. Besaran anggaran yang didapat oleh desa secara tiga tahap, yaitu pertama $30 \%$, kedua $30 \%$ dan ketiga adalah $40 \%$

d. Pada APBN 2015 rata-rata anggaran dana desa diperoleh sebesar Rp.700 Juta yang bersumber dari realokasi: program PNPM Mandiri Perdesaan (Kemendagri), SPAM Perdesaan dan PPIP (Kemen PU).

4. Kesiapan dalam Implementasi UU No. 6 tahun 2014 tentang Desa dan Peraturan Pemerintah No. 60 Tahun 2014 tentang Dana Desa Pemerintah Daerah

1) Menyiapkan Perda APBD yang menampung penerimaan Dana Desa dan alokasi dana desa dari APBN, ADD, bagian hasil pajak dan retribusi daerah.

2) Menyiapkan peraturan bupati/walikota tentang pembagian Dana Desa dari APBN ke masingmasing Desa.

3) Menyiapkan pelatihan kepada aparat desa.

4) Melaksanakan pemantauan dan evaluasi Dana Desa.

5) Menyiapkan laporan pelaksanaan Dana Desa.

5. Penggunaan Dana Desa meliputi:

a. Dana desa digunakan untuk membiayai pembangunan dan pemberdayaan masyarakat desa sesuai dengan prioritas penggunaan dana desa yang ditetapkan oleh Kementerian Desa dan daerah Tertinggal.

b. Penggunaan dana desa untuk kegiatan yang tidak termasuk prioritas dapat dilakukan sepanjang kebutuhan untuk pemenuhan kegiatan pembangunan dan pemberdayaan masyarakat terpenuhi.

c. Penggunaan dana desa untuk kegiatan yang tidak prioritas harus mendapatkan persetujuan bupati/walikota. 
d. Persetujuan bupati/walikota diberikan pada saat evaluasi terhadap rancangan peraturan desa tentang APB Desa.

e. Dalam rangka memberikan persetujuan, bupati/walikota memastikan bahwa pengalokasian dana desa untuk pembangunan dan pemberdayaan masyarakat yang menjadi prioritas telah terpenuhi.

f. Kepala desa bertanggung jawab atas penggunaan Dana Desa

g. Kementerian/lembaga teknis terkait dan kabupaten/kota dapat melakukan pendampingan pelaksanaan dana desa.

6. Sistem Monitoring dan Evaluasi Pembangunan Desa

a. Masyarakat desa berhak mendapatkan informasi mengenai rencana dan pelaksanaan pembangunan desa.

b. Masyarakat desa berhak melakukan pemantauan terhadap pelaksanaan pembangunan desa.

c. Masyarakat desa melaporkan hasil pemantauan dan berbagai keluhan tentang pelaksanaan pembangunan desa kepada pemerintah desa dan Badan Permusyawaratan Desa.

d. Pemeintah desa wajib menginformasikan perencanaan dan pelaksanaan Rencana Pembangunan Jangka Menengah Desa, Rencana Kerja Pemerintah esa, APBDesa kepada masyarakat desa melalui layanan informasi kepada umum dan melaporkan dalam Musyawarah Desa paling sedikit satu tahun sekali.

e. Masyarakat desa berpartisipasi dalam Musyawarah Desa untuk menanggapi laporan pelaksanaan pembangunan desa.

7. Pembinaan dan pengawasan yang dilakukan oleh Pemerintah Daerah kabupaten/Kota meliputi:

a. Memberikan pedoman pelaksanaan penugasan urusan kabupaten/kota yang dilaksanakan oleh Desa;

b. Memberikan pedoman penyusunan Peraturan Desa dan Peraturan Kepala Desa;

c. Memberikan pedoman penyusunan perencanaan pembangunan partisipatif;

d. Melakukan fasilitasi penyelenggaraan pemerintah desa;

e. Melakukan evaluasi dan pengawasan peraturan desa;

f. Menetapkan pembiayaan alokasi dana perimbangan untuk desa;

g. Mengawasi pengelolaan keuangan desa dan pendayagunaan aset desa;

h. Melakukan pembinaan dan pengawasan penyelenggaraan pemerintahan desa;

i. Menyelenggarakan pendidikan dan pelatihan bagi pemerintah desa, BPD, lembaga kemasyarakatan dan lembaga adat.

j. Memberikan penghargaan atas prestasi yang dilaksanakan oleh penyelenggaraan pemerintah desa, BPD, lembaga kemasyarakatan dan lembaga adat;

k. Melakukan upaya percepatan pembangunan desa melalui bantuan keuangan, bantuan pendampingan dan bantuan teknis

I. Melakukan peningkatan kapasitas BUMDesa dan lembaga kerjasama antar desa; 
m. Memberikan sanksi atas penyimpangan yang dilakukan oleh Kepala Desa sesuai dengan peraturan perundang-undangan.

8. Pola Pendampingan Desa (Permendesa No. 3 Tahun 2015)

Tujuan pendampingan desa:

a. Meningkatkan kapasitas, efektivitas dan akuntabilitas pemerintahan desa dan pembangunan desa.

b. Meningkatkan prakarsa, kesadaran dan partisipasi masyarakat desa dalam pembangunan desa yang partisipatif;

c. Meningkatkan sinergi pembangunan desa antar sektor

d. Mengoptimalkan aset lokal desa secara emansipatoris

Ruang lingkup dalam pola pendampingan desa adalah berikut ini:

a. Pendampingan dilakukan secara berjenjang untuk memperdayakan dan memperkuat desa;

b. Pendampingan masyarakat desa sesuai dengan kebutuhan yang didasarkan kondisi geografis wilayah, nilai APBDes dan cakupan kegiatan;

c. Pemerintah secara keseluruhan melakukan upaya pemberdayaan desa melalui pendampingan masyarakat desa yang berkelanjutan termasuk dalam penyediaan sumber daya manusia.

\subsection{Pembahasan}

Berdasarkan analisis data di atas dapat diketahui bahwa kesiapan pemerintah pusat dan pemerintah daerah sudah baik dalam pelaksanaan dalam menyongsong Undang - Undang No. 14 tentang Desa. Tinggal bagaimana kesiapan pemerintah desa dalam merencanakan anggaran, melaksanakan angaran, evaluasi dan pertanggungjawaban pengelolaan dana desa tersebut. Dalam rangka mendukung terwujudnya tata kelola yang baik (good governance) dalam penyelenggaraan desa, pengelolaan keuangan desa dilakukan berdasarkan prinsip tata kelola yaitu transparan, akuntabel dan partisipatif serta dilakukan dengan tertib dan disiplin anggaran.

Prinsip-prinsip transparansi dapat diukur melalui sejumlah indikator (Bappenas 2003) seperti berikut:

a. Mekanisme yang menjamin sistem keterbukaan dan standarisasi dari semua proses pelayanan publik (pembuatan perencanaan anggaran)

b. Mekanisme yang memfasilitasi pertanyaan-pertanyaan publik tentang berbagai kebijakan dan pelayanan publik, maupun proses-proses didalam sektor publik (forum pengajuan RPBDesa oleh Kepala Desa kepada Badan Permusyawaratan Desa untuk dibahas dan disepakati).

c. Mekanisme yang memfasilitasi pelaporan maupun penyebaran informasi maupun penyimpangan tindakan aparat publik didalam kegiatan melayani (adanya laporan realisasi pelaksanaan APBDesa dari Kepala Desa kepada Bupati/Walikota berupa laporan semester pertama dan laporan semester akhir tahun. 
Keuangan desa dikelola berdasarkan asas-asas transparan, akuntabel, partisipatif serta dilakukan secara tertib dan disiplin anggaran. Pengelolaan keuangan desa dikelola dalam masa satu tahun anggaran yaki mulai tanggal 1 Januari sampai dengan tanggal 31 Desember. Dalam pengelolaan keuangan desa, dibuatlah suatu manajemen pengelolaan keuangan desa. Hal pertama yang dilakukan adalah Sekretaris desa menyusun rancangan peraturan desa tentang APBDesa berdasarkan RKP Desa tahun berkenaan. Sekretaris Desa menyampaikan rancangan APBDesa kepada Kepala Desa. Selanjutnya Rancangan APBDesa disampaikan oleh Kepala Desa kepada Badan Permusyawaratan Desa untuk dibahas dan disepakati. Rancangan APBDesa disepakati bersama paling lambat bulan Oktober tahun berjalan. Dalam Peraturan Menteri Dalam Negeri No. 113 Tahun 2014 tentang Pengelolaan Keuangan Desa dibahas tentang:

a. Asas pengelolaan keuangan desa;

b. Kekuasaan pengelolaan keuang desa;

c. APBDesa;

d. Pendapatan;

e. Belanja Desa;

f. Pengelolaan keuangan desa yang mengatur dari perencanaan, pelaksanaan, penatausahaan; pelaporan; pertanggung jawaban serta pembinaan dan pengawasan.

Dalam pelaksanaan akuntabilitas dilingkungan instansi pemerintah, perlu diperhatikan prinsipprinsip sebagai berikut:

a. harus ada komitmen dari pimpinan dan seluruh staf instansi untuk melakukan pengelolaan pelaksanaan misi agar akuntabel;

b. harus merupakan suatu sistem yang dapat menjamin penggunaan sumber-sumber daya secara konsisten dengan peraturan perundang-undangan yang berlaku;

c. harus dapat menunjukkan tingkat pencapaian tujuan dan sasaran yang telah ditetapkan

d. harus berorientasi pada pencapaian visi dan misi serta hasil dan manfaat yang diperoleh;

e. harus jujur, objektif, transparan dan inovatif sebagai katalisator perubahan manajemen instansi pemerintah dalam bentuk pemutakhiran metode dan teknik pengukuran kinerja dan penyusunan laporan akuntabilitas (LAN \& BPKP, 2000).

Dalam hal pertanggungjawaban terhadap pengelolaan keuangan desa, Kepala Desa setiap akhir tahun anggaran menyampaikan laporan pertanggungjawaban realisasi pelaksanaan APBDesa kepada Bupati/Walikota. Dalam menjamin sumber daya yang konsisten, pencapaian tujuan dan sasaran, visi dan misi yang ditetapkan, jujur obyektif dan transparan serta inovatif, semua itu dituangkan dalam laporan pertanggungjawaban realisasi pelaksanaan APBDesa. Laporan pertanggungjawaban realisasi pelaksanaan APBDesa harus dilampiri:

a. format laporan pertangungjawaban realisasi pelaksanaan pelaksanaan APBDesa tahun anggaran berkenaan;

b. format laporan kekayaan milik desa per 31 Desember tahun anggaran berkenaan;

c. format laporan program pemerintah dan Pemerintah Daerah yang masuk ke desa. 
Laporan realisasi dan laporan pertanggungjawaban realisasi pelaksanaan APBDesa diinformasikan kepada masyarakat secara tertulis dan dengan media informasi yang bisa diakses masyarakat misalnya papan pengumuman, radiokomunitas dan media lainnya dan laporan tersebut disampaikan paling lambat satu bulan setelah akhir tahun anggaran berkenaan.

Partisipasi masyarakat dalam penentuan kebijakan publik menjadi kekuatan pendorong untuk mempercepat terpenuhinya prinsip akuntabilitas dari penyelenggara pemerintahan di desa. Dalam penganggaran, partisipasi masyarakat sangat penting untuk mencegah kebijakan-kebijakan yang menyimpang. Prinsip dan indikator partisipasi masyarakat dalam pengganggaran menurut Sulistioni dan Hendriadi (2004) dalam Taufik (2013) mencakup hal-hal berikut:

a. adanya akses bagi partisipasi aktif publik dalam proses perumusan program dan pengambilan keputusan anggaran;

b. adanya peraturan yang memberikan tempat ruang kontrol oleh lembaga independen dan masyarakat baik secara perorangan maupun kelembagaan sebagai media check and balances;

c. adanya sikap proaktif pemerintah daerah untuk mendorong partisipasi warga pada proses penganggaran. Hal ini mengingat kesenjangan yang tajam antara kesadaran masyarakat tentang cara berpartisipasi yang efektif dan cita-cita mewujudkan APBD yang aspiratif.

Partisipasi masyarakat sangat penting dalam perumusan perancangan APBDesa. Badan Permusyawaratan Desa mewakili masyarakat untuk menyampaikan aspirasi dalam pembangunan desa. Masyarakat tetap mendampingi pelaksanaan dan pertanggungjawaban APBDesa sampai tahap akhir yaitu ikut mengevaluasi laporan realisasi dan pertanggungjawaban APBDesa dari media informasi yang disediakan oleh Desa. Pemerintah Propinsi dan Pemerintah Daerah tetap mengadakan pembinaan dan pengawasan pelaksanaan pengelolaan keuangan desa.

Hambatan yang krusial yang dapat ditemui dalam mewujudkan good governance pengelolaan keuangan desa adalah kurangnya sumber daya manusia yang cakap dalam pengelolaan keuangan desa. Sumber daya manusia yang cakap sangatlah dibutuhkan. Hal ini berdasarkan kenyataan banyaknya pamong desa yang tingkat pendidikannya cuma lulusan SMP atau SMA. Sedangkan untuk mengelola dana ratusan juta hingga tirluyan bukanlah hal yang mudah. Perlu adanya sumber daya manusia minimal D3 akuntansi yang dapat mengelola dana desa dengan cekatan. Adanya sumber daya manusia yang terampil dan cekatan dapat mempermudah dalam pelaksanaan pengelooan keuangan desa. Banyak kita temui laporan APBDesa sering terlambat laporannya sehingga menghambat jalannya pengucuran dana. Hal ini juga terkendala sumber daya manusianya.

\section{Kesimpulan, Keterbatasan, dan Saran}

\subsection{Kesimpulan}

Undang-Undang No. 6 Tahun 2014 telah memberikan landasan ideal yang mendudukkan desa dalam kerangka hukum nasional sebagai lokus utama pembangunan nasional yang telah 
memperhatikan hak dan kewenangan desa. Dalam penjabaran UU Desa, salah satu instrumen yang mendasar adalah dengan dialokasikannya dana desa yang bersumber dari APBN, sebagai pengejawantahan paradigma desa membangun, yang memberikan kewenangan sepenuhnya kepada desa dalam membangun kesejahteraan masyarakat desa. Pemerintah mengharapkan adanya transparansi, akuntabel dan partisipasi dalam pengelolaan keuangan desa karena itu merupakan aspek penting dalam menciptakan good governance dalam pengelolaan keuangan desa.

\subsection{Keterbatasan}

Penelitian ini hanya menganalisis data berdasarkan good governance yang ada di teori dengan membandingkan data yang ada di lapangan. Penelitian ini hanya pada waktu persipan desa dalam menerima anggaran dana desa. Penelitian ini belum mengevaluasi corporate governance pada pelaksanaan dan penyelenggaraan program-program pembangunan yang diselenggarakan desa sehingga kurang untuk menginterpretasikan pengelolaan keuangan desa secara keseluruhan pada pelaksanaan program dana desa.

\subsection{Saran}

Penelitian selanjutnya diharapkan memperpanjang waktu penelitian sehingga akan mendapatkan informasi yang lebih banyak dalam pengelolaan keuangan desa. Penelitian ini tujuannya untuk melihat good governance dalam menyongsong pelaksanaan UU No. 6 Tahun 2014 tentang Desa. Untuk penelitian selanjutnya diharapkan dapat menilai efisiensi dan efektivitas dari program-program yang ada di desa dan dapat mengevaluasi penyelenggaran program-program pembangunan yang diselenggarakan desa.

\section{Daftar Pustaka}

Badan Perencanaan Pembangunan Nasional. 2003. Indikator \& Alat Ukur Prinsip Akuntabilitas, Transparansi \& Partisipasi. Jakarta.

Evans, J. H., dan J. M. Patton. 1987. Signaling and Monitoring in Public Sector Accounting. Journal of Accounting Research 25: 130-158.

Nyoto, H., dan F. H. Fadzil. 2011. Fiscal Decentralization after Implementation of Local Government Autonomy in Indonesia. World Review of Business Research 1 (2): 51-70.

Halim, A., dan S. Abdullah. 2006. Hubungan dan Masalah Keagenan di Pemerintah Daeah (Sebuah Peluang Penelitian Anggaran dan Akuntansi). Jurnal Akuntansi Pemerintahan 2 (1): 53-64.

Hardikasari, E. 2011. Pengaruh Penerapan Corporate Governance Terhadap Kinerja Keungan Pada Industri Perbankan yang Terdaftar di Bursa Efek Indonesia (BEI) Tahun 2006-2008. Skripsi. Semarang: Fakultas Ekonomi Universitas Diponegoro.

Lembaga Administrasi Negara dan Badan Pengawasan Keuangan dan Pembangunan. 2000. Akuntabilitas dan Good Governance. Bogor.

Mardiasmo. 2002. Otonomi \& Manajemen Keuangan Daerah. Yogyakarta: Andi

Moe, T.M. 1984. The New Economics of Organization. American Journal of Political Science, 28 (5): 739-777. 
Prasojo, E., dan T. Kurniawan. 2008. Reformasi Birokrasi dan Good Governance: Kasus Best Practices dan Sejumlah Daerah di Indonesia. Makalah disajikan dalam The 5th International Symposium of Jurnal Antropologi Indonesia. Banjarmasin.

Republik Indonesia. 1945. Undang-Undang Dasar Negara Republik Indonesia Tahun 1945. Jakarta.

Republik Indonesia. 2014. Undang-Undang Nomor 6 Tahun 2014 Tentang Desa. Jakarta.

Republik Indonesia. 2004. Peraturan Pemerintah Nomor 33 Tahun 2004 Tentang Perimbangan Keuangan Antara Pemerintah Pusat dan Daerah. Jakarta.

Republik Indonesia. 2006. Peraturan Menteri Dalam Negeri Nomor 13 Tahun 2006 Tentang Pedoman Pengelolaan Keuangan Daerah. Jakarta.

Republik Indonesia. 2007. Peraturan Menteri Dalam Negeri Nomor 37 Tahun 2007 Tentang Pedoman Pengelolaan Keuangan Desa. Jakarta.

Republik Indonesia. 2014. Peraturan Menteri Dalam Negeri Nomor 113 Tahun 2014 tentang Pengelolaan Keuangan Desa. Jakarta.

Republik Indonesia. 2015. Peraturan Menteri Desa, Pembangunan Daerah Tertinggal, dan Transmigrasi Republik Indonesia Nomor 3 Tahun 2015 Tentang Pendampingan Desa. Jakarta.

Santosa, P. 2008. Administrasi Publik Teori dan Aplikasi Good Governance. Bandung: Refika Aditama.

Simanjuntak, D. A., dan Y. Januarsi. 2011. Akuntabilitas dan Pengelolaan Keuangan di Masjid. Makalah disajikan dalam Simposium Nasional Akuntansi XVI. Aceh

Taufik, T. 2013. Pengelolaan Keuangan Desa Dalam Sistem Keuangan Negara Republik Indonesia. Jurnal Ekonomi 17 (01).

Yin, R. K. 2003. Studi Kasus Desain dan Metode. Jakarta: Raja Grafindo Persada

Zimmerman, J. L. 1977. The Municipal Accounting Maze: An Analysis of Political Incentives. Journal of Accounting Research 15: 107-144. 